\title{
Isolation of astaxanthin from marine yeast and study of its pharmacological activity
}

\author{
*Uma Nath Ushakumari', Ravi Ramanujan² \\ ${ }^{1}$ Dale View College of Pharmacy and Research Centre, Punalal, Trivandrum, India \\ ${ }^{2}$ Department of Pharmaceutical Chemistry, Sankaralingham Bhuvaneswari College of Pharmacy, Sivakasi, Tamilnadu, India
}

\begin{abstract}
The aim of the present study was to isolate and study about the antibacterial activity of astaxanthin from marine yeast. Astaxanthin a carotenoid present in marine yeast and crustaceans posses a wide range of pharmacological activity. Yeast strain was isolated from the marine sediments collected from Cochin, Kerala during the month of August 2012. The samples were collected in sterile plastic covers and brought to the laboratory without exposing to the external environment further. The marine sediment samples were directly inoculated in yeast malt. After effective screening the strains containing astaxanthin was refrigerated for further use. The strains were purified by TLC using petroleum hexane: acetone (3:1). A spectrophotometric assay was carried out by measuring absorbance at 200-500nm. The antibacterial activity was studied on several organisms like Bacillus Subtilis, Salmonella typhi, Staphylococcus aureus and Pseudomonas aeroginosa. The extracts showed excellent antibacterial activity than the standard chloramphenicol. Among this, Pseudomonas aeroginasa showed maximum inhibition.
\end{abstract}

Key Words: Astaxanthin, marine yeast, yeast malt, Antibacterial activity fermentation, well diffusion assay.

\section{INTRODUCTION}

Astaxanthin (Figure 1), unlike some carotenoids, does not convert to Vitamin-A (retinol) in the human body. Too much Vitamin $\mathrm{A}$ is toxic for a human, but astaxanthin is not. However, it is a powerful Antioxidant; it is 10 times more capable than other carotenoids. While astaxanthin is a natural nutritional component, it can be found as a food supplement. The supplement is intended for human, animal, and aquaculture consumption. The commercial production of astaxanthin comes from both natural and synthetic sources (Mortensen and Skibsted, 1997; Texier et al., 1984).

The US Food and Drug Administration (FDA) approved astaxanthin as a food colouring (or colour additive) for specific uses in animal and fish foods. The European Union (actually European Commission) considers it food dye within the $\mathrm{E}$ number

\footnotetext{
*Corresponding Author:

Uma Nath Ushakumari

Assistant Professor

Dale View College of Pharmacy and Research Centre

Punalal, Trivandrum, India

E-mail: umaanalysis@yahoo.co.in

Contact No.: +919746755048
}

system. Astaxanthin pronounced as (as-tuh-zan'thin) is a carotenoid. It belongs to a larger class of phytochemicals known as terpenes. It is classified as a xanthophyll, which means "yellow leaves". Like many carotenoids, it is a colorful, fat/oil-soluble pigment. Astaxanthin can be found in microalgae, yeast, salmon, trout, krill, shrimp, crayfish, crustaceans, and the feathers of some birds. Professor Basil Weedon was the first to map the structures of astaxanthin. The study of the pharmacological activity of astaxanthin is vast and wide. The aim and scope of the present research work is to study the anti bacterial activity of astaxanthin (Moren et al., 2002; Lorenz and Cysewski, 2000)

\section{MATERIALS AND METHODS}

\section{Sample collection}

Yeast strain was isolated from the marine sediments collected from Cochin, Kerala during the month of August 2012. The samples were collected in sterile plastic covers and brought to the laboratory without exposing to the external environment further. 


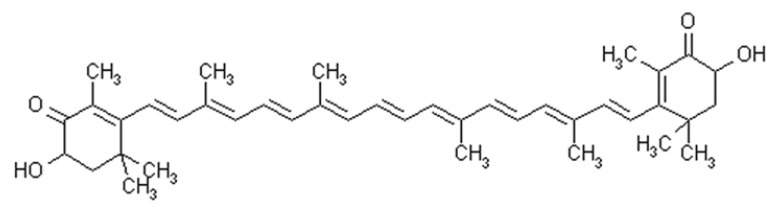

Figure 1: Structure of Astaxanthin.

\section{Isolation of marine yeast}

The marine sediment samples were directly inoculated into Yeast malt (YM) broth fortified with chloramphenicol to prevent bacterial contamination and incubated at $24 \pm 1^{\circ} \mathrm{C}$ for 3 to 5 days. The colonies developed were purified by inoculating each isolates into fresh Yeast malt Agar medium (Table 1). The cultures were screened for astaxanthin production and the efficient strain producing astaxanthin was periodically subcultured and refrigerated for further use.

\section{Aspergillus (crude saccharidase) preparation}

$20 \mathrm{~g}$ bran, $5 \mathrm{~g}$ flour and $20 \mathrm{ml}$ water were taken and mixed into $500 \mathrm{ml}$ Erlenmeyer flask, sterilized at $121^{\circ} \mathrm{C}$ for $20 \mathrm{~min}$. Then the solution was cooled to $30^{\circ} \mathrm{C}$ and inoculated Aspergillus niger AS. 3.278 and Aspergillus flavus AS. 3.800, respectively under aseptic condition. They were cultured at $30^{\circ} \mathrm{C}$ for 12 hrs. Closing the flask till mycelium grown over shake flask and forming into shape of pie in $24 \mathrm{~h}$, continue culturing till substrate were fully grown in spore. The overall procedure would take $72 \mathrm{~h}$ or so.

\section{Saccharification of Cassava Residues}

$100 \mathrm{~g}$ cassava residues was taken into $1000 \mathrm{ml}$ triangular flask, $700 \mathrm{ml}$ water was added and sterilized at $121^{\circ} \mathrm{C}$ for $20 \mathrm{~min}$. After sterilization, cultured aspergillus preparation was added (3g AS. 3.800 and $7 \mathrm{~g}$ AS.3.2783) and saccharified at $58^{\circ} \mathrm{C}$ for $5 \mathrm{hrs}$.

\section{Nitrogen sources medium}

Saccharified cassava residues were filtered for solution. Sugar degree was adjusted to $30 \mathrm{~g} / \mathrm{L}$ through glucose, $\mathrm{KH}_{2} \mathrm{PO}_{4}$ of $1.5 \mathrm{~g} / \mathrm{L}, \mathrm{MgSO}_{4}$ of $0.5 \mathrm{~g} / \mathrm{L}$, were added. $5 \mathrm{~g} / \mathrm{L}$ of peptone, yeast extract, beef extract, $\mathrm{KNO}_{3},\left(\mathrm{NH}_{4}\right)_{2} \mathrm{SO}_{4}$ and $\mathrm{NH}_{4} \mathrm{NO}_{3}$ were added. Then, it was transferred into $100 \mathrm{ml} / 500 \mathrm{ml}$ triangular flask, and sterilized at $121^{\circ} \mathrm{C}$ for $20 \mathrm{~min}$.

\section{Growth medium}

Saccharified cassava residues were filtered for solution. Sugar degree was adjusted to $30 \mathrm{~g} / \mathrm{L}$
Table 1: Composition of the medium of extraction

\begin{tabular}{lll}
\hline \multirow{2}{*}{ Ingredients } & \multicolumn{2}{l}{ Amount in grams/litre } \\
\cline { 2 - 3 } & Yeast malt & Yeast malt agar \\
\hline Peptic digest of & 5.0 & 5.0 \\
animal tissue & 3.0 & 3.0 \\
Yeast extract & 3.0 & 3.0 \\
Malt extract & 10.0 & 10.0 \\
Dextrose & - & 20.0 \\
Agar & $6.2 \pm 0.2$ & - \\
Final pH &
\end{tabular}

through glucose, yeast extract of $3 \mathrm{~g} / \mathrm{L},\left(\mathrm{NH}_{4}\right)_{2} \mathrm{SO}_{4}$ of $2 \mathrm{~g} / \mathrm{L}, \mathrm{KH}_{2} \mathrm{PO}_{4}$ of $1.5 \mathrm{~g} / \mathrm{L}$, and $\mathrm{MgSO}_{4}$ of $0.5 \mathrm{~g} / \mathrm{L}$ were added and transferred into $100 \mathrm{ml} / 500 \mathrm{ml}$ triangular flask, respectively and sterilized at $121^{\circ} \mathrm{C}$ for $20 \mathrm{~min}$.

\section{Analytical methods \\ Pigment extraction}

The extraction and analysis of Astaxanthin content in the yeast cells followed the methods as described by $\mathrm{Du}$ et al. (2008). Yeast biomass was separated from the liquid medium by centrifuging and rinsed twice with double distilled water. The yeast was disrupted with dimethyl sulphoxide (DMSO) and then extracted with Acetone. The amount of Astaxanthin was calculated from the absorbance measured at 480nm multiplying an extinction coefficient of 2150 .

\section{Dry weight determination}

Yeast biomass was separated from the liquid medium by centrifuging and rinsed twice with double distilled water, and then dried at $105^{\circ} \mathrm{C}$ overnight to constant weight, yielding the dry weight.

\section{Study of antibacterial activity}

Agar diffusion assay is used widely to determine the anti-bacterial activity of Leaf extract. The technique works well with defined inhibitors (Hewit and Vincent, 1989). Nutrient agar prepared was poured in the Petri dish. 24 hours growing culture (Salmonella typhi; Pseudomonas aeruginosa; Bacillus subtilis and Staphylococcus aureus) were swabbed on it. The wells $(10 \mathrm{~mm}$ diameter) were made by using cork borer. The different concentrations of the crude extract were loaded in the wells. The plates were then incubated at $37^{\circ} \mathrm{C}$ for 24 hours. The inhibition diameter was measured (Figure 2). 


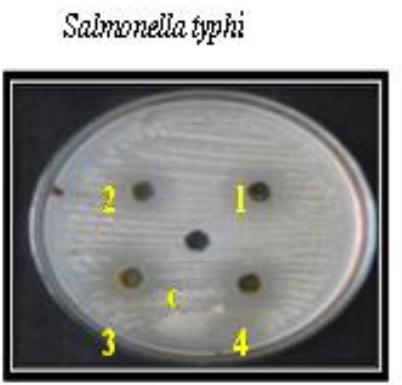

Psedomonos aerginosa

Saphylococcus aurets
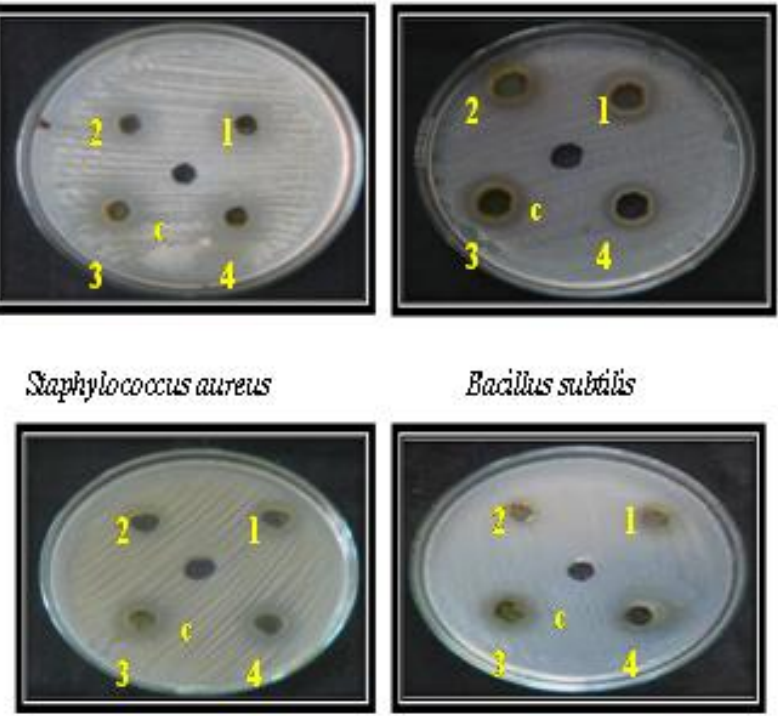

Bacillus subtilis

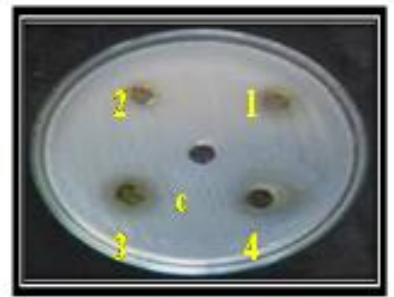

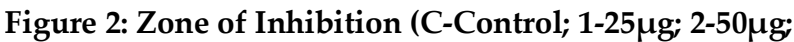

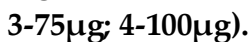

Table 2: Diameter of zone of inhibition of extracts on various microorganisms.

\begin{tabular}{llll}
\hline S1 & Microorganism & Extract & Standard \\
No. & & & \\
\hline 1 & Salmonella typhi & 20 & 24.5 \\
2 & Pseudomonas aeruginosa & 22 & 21 \\
3 & Bacillus subtilis & 18 & 24 \\
4 & Staphylococcus aureus & 16 & 23 \\
\hline
\end{tabular}

\section{RESULTS AND DISCUSSION}

Table 1 shows the composition of medium of extract. Table 2 shows the diameter of zone of inhibition of extracts on various microorganisms when compared to the standard. Figure 2 shows the well diffusion assay zones produced by standards and various microorganisms. The antibacterial activity of the extract was studied by using well diffusion method Salmonella typhi produced $20 \mathrm{~mm}$ diameter for zone of inhibition, Pseudogonas aeroginasa $24 \mathrm{~mm}$, Bacillus subtilis $18 \mathrm{~mm}$. Staphylococcus aureus $16 \mathrm{~mm}$. The extract showed excellent antibacterial activity than the standard chloramphenicol. Among this, Pseudomonas aeroginasa (Figure 2, Table 2) showed maximum inhibition.

\section{CONCLUSION}

Astaxanthin is effective against gram positive and gram negative bacteria when compared with standard chloramphenicol. However the experiments have to be tried by using different solvents.

\section{REFERENCES}

Asker, D., Amano, S., Morita, K., Tamura, K., Sakuda, S., et al. (2009) Astaxanthin dirhamnoside, a new astaxanthin derivative produced by a radio-tolerant bacterium, Sphingomonas astaxanthinifaciensAstaxanthin dirhamnoside, The Journal of Antibiotics, 62:397-399. [DOI]

Attoe, E. L., von Elbe, J.H. (1985). Oxygen involvement in betanine degradation: effect of antioxidants, Journal of food science, 50: 106-110. [DOI]

Ausich, R.L., Sanders, D.J. (1997) Process for the formation, isolation and purification of comestible xanthophyll crystals from plants. US Patent 5: 648, 564.

Britton G., Armitt, G.M. Lau, S.Y.M. Patel, A.K., Shone, C.C. (1981). Carotenoproteins, in Carotenoid Chemistry \& Biochemistry (ed. by G. Britton and T. W. Goodwin), Pergamon Press, Oxford, Pp. 237-251.

Calnan, C.D. (1976). Quinazoline yellow SS in cosmetics. Contact Dermatitis, 2(3): 160- 166. [DOI]

Delgado-Vargas, F., Jiménez, A.R., Paredes-López, O. (2000). Natural pigments: carotenoids, anthocyanins, and betalains--characteristics, biosynthesis, processing, and stability. Crit Rev Food Sci Nutr, 40(3):173-289. [DOI] PMid:10850526

Delgado-Vargas, F., Paredes-Lopez, O. (1997). Effects of enzymatic treatments of marigold flowers on lutein isomeric profiles, Journal of Agricultural and Food Chemistry, 45(4): 1097-1102. [DOI]

Dietmar, E., Breithaupt, Jorg Schlatterer. (2005). Lutein and Zeaxanthin in new dietary supplements- analysis and quantification, European Food Research and Technology, 220: 648-652. [DOI]

Du, S.J., Mei, Y.Z., Hu Y.H., et al. (2008). Optimization of culture conditions for producing astaxanthin by phaffia rhodozyma. Food Science, 29(8) 441-444.

Hardy, R. W. (2001). Pigmentation of salmonids with Haematococcus algae meal (NatuRose Aquaculture Research Institute, University of Idaho, Hagerman, Idaho. Davis B.H. (1985) Carotenoid metabolism in animals: A biochemist's view, Pure Appl. Chem., 57: 679-684.

Lorenz, R.T., Cysewski, G.R. (2000). Commercial potential for Haematococcus microalgae as a natural source of astaxanthin, Trends Biotechnol, 18: 160-167. [DOI]

Moren, M., Næss, T., Hamre, K.(2002). Conversion of $\beta$-carotene, canthaxanthin and astaxanthin to vitamin A in Atlantic halibut (Hippoglossushippoglossus L.) juveniles, Fish Physiology and Biochemistry, 27(1-2): 71-80 [DOI]

Mortensen, A., Skibsted, L.H. (1997). Importance of Carotenoid Structure in Radical-Scavenging Reactions, Journal of Agriculture and Food Chemistry, 45(8): 2970-2977. [DOI]

Naguib YM. (2000). Antioxidant activities of astaxanthin and related carotenoids. J Agric Food Chem, 48(4):1150-1154. [DOI] PMid:10775364

Sarada, R., Vidhyavathi, R., Usha, D., Ravishankar, G.A. (2006) An efficient method for extraction of astaxanthin from green alga haematococcuspluvialis. Journal of Agricultural and Food Chemistry, 54: 7585-7588. [DOI] PMid:17002425

Sommer, T. R., W. T. Potts, and N. M. Morrissy. (1991). Utilization of microalgal astaxanthin by rainbow trout (Oncorhynchusmykiss). Aquaculture, 94: 79-88. [DOI]

Texier, O., Pourrat, H., Pourrat, A., Barthomeuf, C. (1984) Purification of ficariasaponins by saccharomyces beticus, penicilliumrugulosum and aspergillusniger, Biotechnology Letters, 6(4): 243-246. [DOI]

Yamane, Y., Mikami, T., Higashida, K., Kakizono, T., Nishio, N. (1996). Biotechnology Techniques, 10(7): 529-534. [DOI] 